\title{
BRIDLINGTON CRAG.
}

SrR,-The shelly patches in the Basement Boulder-clay at Bridlington, known as the "Bridlington Crag," have been so long inaccessible that it may interest glacial geologists to know that these beds are being temporarily exposed in the foundations for a new sea-wall. It is now twenty-one years ago since these shelly patches were last seen, in a brief exposure on the foreshore, and when the new wall is built they will be more hopelessly hidden than ever.

The excavations are carried on between tide-marks, in short lengths which are filled in at once. The section which I saw three weeks ago during a hasty visit to Bridlington showed about 5 feet of Boulder-clay with narrow streaks and dabs of richly glauconitic sand full of broken shells. I learn that, in other places, larger patches of the sand, with some unbroken shells, have been found, like the masses which I saw and described in 1882-3.

It is satisfactory to be able to add that the East Yorkshire geologists are alive to the opportunity, and are taking steps to secure material for the further study of this exceptionally interesting Arctic fauna.

G. W. Lamplogh.

Deburs.

OBITUAFY.

\section{LIEUT.-GENERAL CHARLES ALEXANDER MCMAHON, F.R.S., F.G.S. \\ Bonx March 23, 1830 . \\ Dimd Felrecarx 21, 1904.}

WE regret to record the loss of an excellent geologist and petrologist, and a prominent Fellow of the Geological Society of London.

The name of General McMahon suggests the thought of the number of Army officers who have taken up our science as a pursuit and achieved distinction, either in geology, palæontology, or in mineralogical geology, often without any early scientific training, as was the case with General McMahon. We recall the names of General Portlock, Sir Roderick Murchison, General Strachey, General Sir Proby T. Cautley, General Hardwieke, General F. T'. Hobson, Colonel Godwin-Austen, Captain Hutton, Major Brickenden, Major Broom, Captain H. G. Lyons, Dr. Leith Adams, and many others. How great would be the list if our cadets at Woolwich, Sandhurst, and elsewhere were encouraged to work at such subjects by means of lectures, laboratories, museums, and field-work, proficiency to be rewarded by suitable marks in examinations!

Charles Alexander McMahon was born at Highgate 23rd March, 1830, and was the son of Captain Alexander McMahon, of the H.E.I.C. Service. He served for eight years in the 39 th M.N.I., and for thirty years on the Punjab Commission. He was late Commissioner of Lahore and a Fellow of Lahore University.

Although, outside his official life, Lieut.-General C. A. McMahon was well known as an ardent and able geologist, his name is 
remembered in India for the thirty years of excellent work as a Commissioner and Civil Judge. The most exciting period of his career was at the time of the Indian Mutiny, when, as a young man under thirty, he was suddenly called upon to assume charge of the Sialkot district, just at the moment (May, 1857) when the native troops rose in revolt. Lieutenant McMahon managed to send off a few lines to General John Nicholson, who was taking a movable column to Delhi. This prompt action led to the mutineers being met and destroyed by Nicholson at the action of 'Trimmos Ghat.

When Commissioner of Hissar, in 1871, General MeMahon took up the study of geology and petrology; and when on furlough to England in 1879-80 he joined the Royal School of Mines, studying geology under Professor Judd, mineralogy under Sir Warington Smyth, and biology under Professor Huxley. Professor Judd writes:- " On his return to India he took up a series of geological studies of the granites and other rocks of the Himalayas, the result of his labours being given to the world in a number of papers published in the Records of the Geological Survey of India. After his retirement he continned these researches with the same enthusiasm as before, devoting special attention to petrological and mineralogical investigations. Even after the failure of his health, and when afflicted with almost complete blindness, he not only maintained an interest in his favourite pursuit, but dictated a paper which appeared quite recently in the Geologicat Magazink." $\mathrm{He}$ became a Fellow of the Geological Society in 1878 , and received the Lyell Medal in 1899 " in recognition of the value of his services to petrology, and more particularly of the work done by him in India." He served on the Conncil, was a Vice-President of the Geological Society; and President of the Geological Section of the British Association at Belfast in 1902. He was elected President of the Geologists' Association in 1894-95. Dr. W. 'T. Blanford, a valued friend of General McMahon's, and for 30 years connected with the Geological Survey of India, says:- "In the exploration of the principal rock groups in the Western Himalayas he was a pioneer, and his discoveries were of great scientific importance. From 1877 to 1887 General Mc.Mahon contributed 24 papers to the Records of the Geological Survey of India, for the most part descriptive of the geology and petrology of districts in the Simla area, thence northward to Spiti, and around Dalhousie and Chamba, and in a few other localities. The so-called Himalayan Central Gneiss he showed to be an intrusive granitic formation." The death of General McMation closes a strenuous life of recognized service to Goverument in his administrative career in India, and of fruitful scientific research in geology, a combination testifying to intellectual equipment unusually varied and to uncommon mental energy maintained until the very last.

General McMahon married, first, Elizabeth, duughter of Colonel C. F. Head, late Queen's Royal Regiment, and secondly, Charlotte

1 Tovember, 1903, 1. 492. 
Emily, daughter of Mr. Henry Dorling, of Stroud Green House, Croydon, who survives him. The distinguished Indian frontier political officer, Lieutenant-Colonel A. H. McMahon, C.S.I., C.I.E., F.R.G.S., F.G.S., Judicial Commissioner at Quetta, Beluchistan, is his eldest surviving son. (In part from The Times.)

LIST OF PAPERS BY LIEUT.-GENERAL C. A. MCMAHON.

"The Blaine Group and the "Central Gueiss' in the Simla Himalayas": India, Geol. Survey Records, x (1877), pp. 204-223.

"Notes of a Tour through Hangrang and Spiti": India, Geol. Survey Records, xii $(1879)$, pp. $57-69$.

"Notes on the Section from Dalhousie to Pangi, riâ the Sach Pass": India, Geol. surver Records, xiv (1881), pp. 305-310.

"The Geology of Dalhousie, North-West Himalaya": India, Geol. Survey Records, $\mathrm{xv}(1882)$, pp. 34-51.

"On the Traps of Darang and Mandi in the North-West Himalayas": India, Geol. Survey Records, $\mathrm{xv}$ (1882), pp. 15j-164.

"Some Notes on the Geology of Chamba": India, Geol. Surrey Records, xvi (1883), pp. $35-42$.

"On the Basalts of Bombay": India, Geol. Surrer Records, xvi (1883), pp. 42-50.

"On the Microscopic Structure of some Dalhousie Rocks": India, Geol. Survey Records, xvi (1883), pp. 129-144.

"On the Lavas of Aden": India, Geol. Survey Records, xri (1883), pp. 145-158.

" (On the Altered Basalts of the Dalhousie Region in the North-Western Himalayas": India, Geol. Survey Records, xvi (1883), pp. 186-192.

"On the Microscopic Structure of some Sub-Himalayan Rocks of Tertiary Age" : India, Geol. Survey Records, xvi (1883), pp. 186-192.

"Note on the Foliation of the Lizard Gabbro": Geol. Mag., Dec. III, Vol. IV (1887), pp. 74-77.

"The Gueissose Granite of the Himalayas": Grol. Mag., Dec. III, Vol. IV (1887), pp. 212-220; Vol. V (1888), pp. 61-65.

"On a mode of using the Quartz Wedge for estimating the strength of the Double Refraction of Minerals in thin slices of Rock": GEoL. MaG., Dec. III, Vol. V (1888), pp. 548-553.

"Notes on the Hornblende-Schists and Banded Crrstalline Rocks of the Lizard": Quart. Journ. Geol. Soc., vol. xlv (1889), pp. $\check{5} 19-544$.

"Notes on the Culm-Measures at Bude, North Cornwall": GeoL. MaG., Dec. III, Vol. VII (1890), pp. 106-117 and 222-226.

(With Boxyey, 'T. G.) "Results of an Examination of the Crystalline Rocks of the Lizard District": Quart. Journ. Geol. Soc., vol. xlvii (1891), pp. 464-499.

"The Manufacture of Serpentiue in Nature's Laboratory: a Reply": Grol. Mag., Dec. III, Vol. IX (1892), pp. 71-76.

“Notes on Dartmoor": Quart. Journ. Geol. Soc., vol, xlix (1893), pp. 385-397.

“Trachrtes, Metamorphic Tuffs, and other Rochs of Igneous Origin on the West Flank of Dartmoor": Quart. Journ. Geol. Soc., rol. I (1894), pp. 338-366.

“The Rape of the Chlorites": Geol. Mag., Dec. IV, Yol. I (1894), pp. 111-114.

(With Hetchings, W. M.) " Yote on Pseudo-Spherulites"; Geol. MAG., Dec. IV, Vol. II (1895), pp. 257-259.

Presidential Address to the Geologists' Association, February 1st, 1895.

Appendix to W. H. Hudlestos's paper on Indian Geology: Proc. Geol. Assoc., vol. xiv (1896), p. 292.

"Notes on the Age and Structure of the Gueissose Granite of the Himalayas with reference to Mr. Middlemiss's Memoir on the Geology of Hazara": Geol. MaG., Dec. IV, Vol. IV (1897), pp. 304-313 and 345-35̄.

"Notes on some Volcanic and other Rocks which occur near the Baluchistan-Afghan Frontier, between Chaman and Persia": Quart. Journ. Geol. Soc., rol. liii (1897), pp. 289-309.

"On the occurrence of Allanite in the Hornblende-Granite of Lairg, Sutherlandshire": Geot. MaG., Dec. IV, Yol. VI (1899), pp. 194-196.

"Notes on the Geology of Gilgit": Quart. Journ. Geol. Soc., rol. lvi (1900), pp. 337-369.

Presidential Address to Section C (Geolngr), British Association, Belfast, 1902.

"Further Remarks on Granite": Geos. MAG., Nov. 1903, pp. 492-499. 